\title{
Redactioneel
}

\section{Nieuw tijdschrift voor actualiteiten en vraagstukken voetbal- en sportrecht}

Tim Wilms*

Met veel plezier en trots presenteren wij u de eerste editie van ons nieuwe tijdschrift Voetbal- E Sportjuridische Zaken. Het tijdschrift komt voort uit de passie van de redactie voor voetbal- en sportrecht alsmede uit het enthousiasme van zowel de uitgever Boom juridisch als de redactieleden om bij te dragen aan regelmatig verschijnende wetenschappelijke publicaties op dit gebied.

Profsport, en met name voetbal, is in Nederland veelvuldig in de actualiteit. Een groot deel van Nederland leeft mee als het Nederlands elftal het EK speelt, als Dafne Schippers de 100 meter finale op de Olympische Spelen loopt of als Max Verstappen met Lewis Hamilton om de wereldtitel in de F1 strijdt. Dat ook de juridische ontwikkelingen met veel belangstelling worden gevolgd blijkt wel uit de massale media-aandacht die enkele jaren geleden de kortgedingzittingen inzake Yuri van Gelder/NOC*NSF en FC Tmente/KNVB trokken. Maar ook bijvoorbeeld uit de recente media-aandacht voor het initiatief van een aantal Europese topclubs om een European Super League te beginnen buiten UEFA om.

Dit soort zaken zullen centraal komen te staan in dit tijdschrift, Voetbal- ES Sportjuridische Zaken. Het doel van het tijdschrift is het geven van juridische duiding aan en opinies over relevante en recente sportjuridische ontwikkelingen met een bijzondere focus op voetbal. Elk nummer zal bestaan uit onder andere wetenschappelijke artikelen, rechtspraakoverzichten en annotaties. Het tijdschrift zal ook aandacht besteden aan ontwikkelin-

* Mr. T.A. (Tim) Wilms is advocaat arbeidsrecht en sport bij Kennedy Van der Laan. gen, reglementswijzigingen en governance vraagstukken in het voetbal en de sport.

De samenstelling van en diversiteit binnen de redactie is een goede afspiegeling van alle relevante juridische kwesties die spelen binnen dit enerverende speelveld. Denk daarbij niet alleen aan de aanwezige expertise op het gebied van het arbeidsrecht en Europees recht, maar in het bijzonder is de kennis ook aanwezig van de relevante nationale en internationale reglementen die een belangrijke rol spelen. Daarnaast zijn de redactieleden vanuit hun professie ook veelal betrokken bij kwesties binnen het voetbal en de sport en is zowel de wetenschappelijke expertise als praktijkkennis optimaal aanwezig.

Naast de Nederlandse aangelegenheden zal met name ook bijzondere aandacht worden gegeven aan de relevante internationale ontwikkelingen en rechtspraak. In de periodieke rechtspraakoverzichten zal niet enkel op de Nederlandse civiele rechtspraak en de beslissingen van de KNVB worden ingegaan, maar ook op de internationale uitspraken van de geschil beslechtende instanties bij FIFA en het sportarbitragehof Court of Arbitration for Sport (CAS). Het tijdschrift zal driemaal per jaar verschijnen.

In deze eerste editie is ervoor gekozen om een aantal actuele zaken te bespreken die de afgelopen maanden de sportjuridische wereld hebben beziggehouden. An Vermeersch, gastprofessor Sportrecht Universiteit Gent, bespreekt de implicaties van de recente uitspraak van het Gerecht van de EU in de $I S U$-zaak voor een mededingingsrechtelijke toetsing van de plannen voor de European Super League alsmede de reactie van UEFA en FIFA daarop. Herman Ram, voorzitter van de Dopingautoriteit, gaat in zijn bijdrage in op de actuele 
stand van zaken van de dopingproblematiek in het voetbal en vergelijkt deze met de problematiek in andere sporten. Deze bijdrage wordt gevolgd door een artikel over mensenrechten omtrent het FIFA WK in Qatar, waarbij Daniela Heerdt, onderzoeker aan de Universiteit van Tilburg, ingaat op de mensenrechtenschendingen rondom arbeidsmigranten in Qatar. Zij bespreekt de verschillende verantwoordelijkheden van de diverse betrokken partijen en analyseert de uitdagingen om de verantwoordelijken ter verantwoording te roepen. Redactieleden Niels Jansen en Tim Wilms bespreken in een afzonderlijke bijdrage het collectief akkoord over salarisverlaging in het Nederlandse profvoetbal en zetten uiteen in welke mate voetbalclubs van hun voetballers kunnen verlangen dat zij genoegen nemen met salarisvermindering. Redactielid Dolf Segaar bespreekt het recent gepubliceerde rapport 'Ongelijke Leggers' dat ziet op het onderzoek naar grensoverschrijdend gedrag in de gymsport. Het nummer wordt afgesloten met overzichten van de meest relevante nationale en internationale rechtspraak in 2020 .

Auteurs die geïnteresseerd zijn om te publiceren in het tijdschrift zijn van harte uitgenodigd om contact op te nemen met de redactie via vsz@boom.nl. Het tijdschrift accepteert zowel Nederlands- als Engelstalige bijdragen.

Wij wensen u veel leesplezier toe.

De redactie,

2 Tim Wilms, advocaat Kennedy Van der Laan

Frans de Weger, advocaat BMDW advocaten, CAS-arbiter

Ben Van Rompuy, universitair docent Universiteit van Leiden

Niels Jansen, universitair docent Universiteit van Amsterdam

Dolf Segaar, advocaat Segaarlaw 